\title{
Antibody to a 63 kilodalton insect protein in ankylosing spondylitis
}

\author{
S R Brand, J Worthington, D P McIntosh, R M Bernstein
}

\begin{abstract}
Ankylosing spondylitis (AS) is associated with antibodies to a heat shock puff on drosophila chromosomes. This observation was investigated by immunoblotting using extracts of the Schneider insect cell line and HeLa cells, before and after heat shock.

An insect protein of 63 kilodaltons (but no equivalent human protein) was recognised by $21(46 \%)$ of 46 serum samples from patients with AS, one of two patients with Reiter's syndrome, four (7\%) of 60 patients with systemic lupus erythematosus, and two (4\%) of 50 control subjects, but not by serum samples from patients with rheumatoid arthritis (RA). Previous heat shock did not appear to affect the strength of reaction, but ML-30, a monoclonal antibody to the mycobacterial 65 kilodalton heat shock protein (hsp65), also recognised an insect protein of 63 kilodaltons by immunoblotting. Antibodies to recombinant mycobacterial hsp65 were measured by enzyme linked immunosorbent assay (ELISA) in serum samples from patients with AS and RA. IgA binding to hsp65 was increased in $41 \%$ of AS and $19 \%$ of RA serum samples, but there was no correlation with detection of antibody to the insect 63 kilodalton protein.
\end{abstract}

Ankylosing spondylitis (AS) is an inflammatory disease of the spine and sometimes the eyes, joints, and other organs. Intestinal carriage of klebsiella, and infection with organisms such as salmonella and yersinia may play a part in triggering the disease, although susceptibility is conferred by the HLA-B27 antigen and preexisting psoriasis, ulcerative colitis, or Crohn's disease. ${ }^{1}$ How the spine and sometimes joints, heart, and lungs become the targets remains uncertain, but sensitised $\mathrm{T}$ lymphocytes are thought to mediate damage, possibly reacting against an antigen expressed at the cell surface in association with HLA-B27 itself. Serological autoimmune responses are well known in other inflammatory rheumatic diseases such as rheumatoid arthritis (RA) and the connective tissue diseases, but antibody responses in AS have received less attention. Increased levels of serum $\operatorname{IgA}$ are well recognised in some patients, autoantibodies to HLA-B27 have been reported, ${ }^{2}$ and antibodies to bacteria have been studied. ${ }^{3}$ There is one report of a specific antibody response in AS, directed at heat shock puffs of Drosophila melanogaster larvae. ${ }^{4}$

Heat shock, warming cells a few degrees above their physiological temperature, and various other physical and chemical stresses cause a reduction in the synthesis of many cellular proteins and increased synthesis of the so called heat shock or stress proteins. The heat shock response has been observed in every organism studied from bacteria to humans, and heat shock genes are highly conserved. ${ }^{5}$ The response is protective overall, and some heat shock proteins act as molecular chaperones maintaining the solubility of immature proteins during the final stages of synthesis and transport. ${ }^{6}$ Synthesis of heat shock proteins is a normal cellular function which is amplified under conditions of physiological stress, perhaps to protect proteins from denaturation. One particular heat shock protein, hsp65, is a dominant antigen in the immune response to microorganisms. ${ }^{7}$

The heat shock phenomenon was first observed as the development of chromosomal puffs in Drosophila melanogaster larvae. ${ }^{8}$ Using such chromosomes as substrate for immunofluorescence, Lakomek et $\mathrm{al}^{4}$ observed that serum samples from $39 \%$ of patients with AS contained an antibody which reacted with heat shock puffs, especially the chromosomal 93D locus. In preliminary experiments we confirmed this finding, but the procedure was technically demanding, difficult to standardise, and in our hands not suitable for the investigation of large numbers of serum samples (Hilton J, Bernstein $\mathrm{R} M$, unpublished data). This report describes our findings with an immunoblotting system for the detection of antibodies to insect proteins. We studied an antibody to a 63 kilodalton protein from insect cells and investigated the cross reactivity with a well characterised mycobacterial heat shock protein of similar molecular weight, hsp65.

\section{Materials and methods}

SOURCE OF SERUM SAMPLES

Serum samples were obtained from patients attending the rheumatology department at Manchester Royal Infirmary. Patients with AS $(n=46), R A(n=20)$, and systemic lupus erythematosus (SLE) $(n=60)$ fulfilled the appropriate classification criteria. ${ }^{-11}$ Serum samples were also obtained from patients with Reiter's syndrome $(n=2)$, polymyositis $(n=3)$, systemic sclerosis $(n=2)$, and adult Still's disease $(n=2)$. As healthy controls, serum samples were obtained from the Regional Blood Transfusion Service, and three additional serum samples from healthy HLA-B27 positive subjects were obtained from the regional tissue typing laboratory. Thirty of the 46 subjects with AS were tested for HLA-B27, and clinical details 
obtained by a review of their case notes are shown in the table. Ankylosing spondylitis was considered active when there was a marked early morning exacerbation of back pain and stiffness. The patients with RA were aged 25-70 years; 15 were women, and arthritis was judged by clinical impression to be severe in 15 and active in six patients; 15 were positive for IgM rheumatoid factor.

\section{CELL CULTURE}

Schneider cells, a continuous line derived from Drosophila melanogaster, were maintained in culture at room temperature $\left(25^{\circ} \mathrm{C}\right)$ in Schneider's drosophila medium (Gibco) supplemented with $10 \%$ fetal calf serum and antibiotics (penicillin $100 \mathrm{IU} / \mathrm{ml}$; streptomycin $100 \mu \mathrm{g} / \mathrm{ml}$ ). Viability, assessed by trypan blue dye exclusion, was greater than $85 \%$ in cells used to make the extracts. HeLa cells were grown in suspension culture under standard conditions. ${ }^{12}$

\section{INDUCTION OF HEAT SHOCK PROTEINS IN} SCHNEIDER CELLS

Conditions required for the induction of a heat shock response in Schneider cells were determined by metabolic labelling of cells, analysis of proteins by sodium dodecyl sulphate polyacrylamide gel electrophoresis, ${ }^{13}$ and autoradiography. Schneider cells $\left(1 \times 10^{8} / \mathrm{ml}\right.$ were maintained in leucine free complete medium at room temperature $\left(25^{\circ} \mathrm{C}\right)$ for 30 minutes. Aliquots $(200 \mu \mathrm{l})$ of cell suspension were then incubated at $25,30,33$, or $37^{\circ} \mathrm{C}$ for one hour in the presence of $>40 \mathrm{kBq}\left[{ }^{3} \mathrm{H}\right]$ leucine (specific activity $5 \cdot 18 \mathrm{TBq} / \mathrm{mmol}$ ). Protein synthesis was terminated by the addition of $10 \%$ cold trichloroacetic acid $(600 \mu \mathrm{l})$. Precipitated protein was washed in $95 \%$ ethanol and resuspended in Laemmli buffer $(75 \mu \mathrm{l})$. Schneider cell protein extracts were electrophoresed on $12.5 \%$ sodium dodecyl sulphate polyacrylamide gels. Gels were fixed and soaked in Amplify (NAMP 100, Amersham International) for $\mathbf{3 0}$ minutes, dried, and autoradiographed.

Warming Schneider cells to a few degrees above room temperature produced the heat shock response shown in fig 1 . Synthesis of a small number of heat shock proteins was induced, predominantly 77 and 86 kilodaltons, and was optimal at $33^{\circ} \mathrm{C}$. Subsequently, a heat shock extract was prepared from Schneider cells maintained in culture in complete medium and warmed to $33^{\circ} \mathrm{C}$ for one hour before lysis.

\section{ANTIGEN PREPARATION}

Schneider and $\mathrm{HeLa}$ cells $\left(1 \times 10^{10}\right)$, heat shocked and not heat shocked, were harvested and washed three times in phosphate buffered saline, resuspended in $100 \mathrm{ml}$ cold lysis buffer $(0.01 \mathrm{~mol} / 1$ TRIS buffer, $\mathrm{pH} 7 \cdot 4,0.15 \mathrm{~mol} / 1$ sodium chloride, $1 \mathrm{mmol} / \mathrm{l}$ phenylmethylsulphonyl fluoride, $1 \%$ aprotinin, $1 \%$ Triton) and left on ice for 10 minutes. Protein was precipitated by the addition of $40 \%$ trichloroacetic acid $(10 \mathrm{ml})$ and pelleted by centrifugation

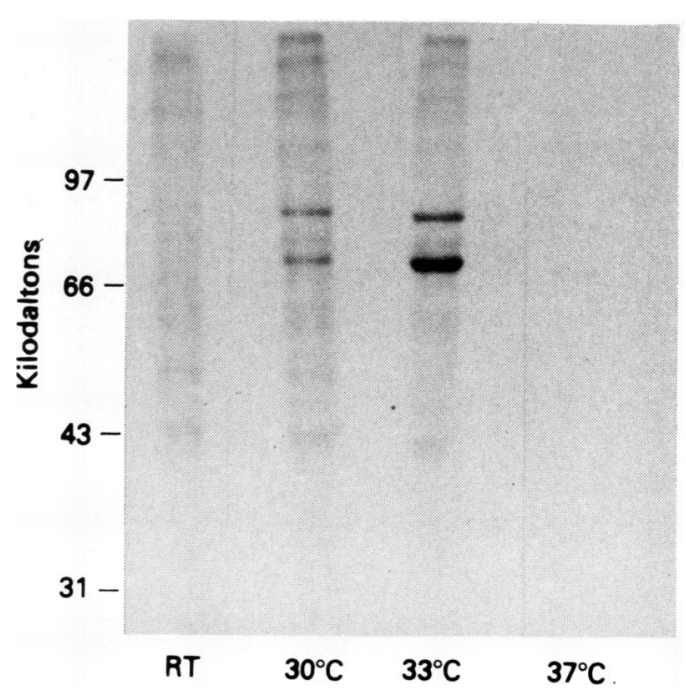

Figure 1 Autoradiography of Schneider cell heat shock proteins following separation of cell extracts on a $12 \cdot 5 \%$ Laemmli gel. Cells were grown at room temperature $(R T)$ then incubated in the presence of $\left[{ }^{3} \mathrm{H}\right]$ leucine at increased temperatures for one hour before lysis.

$\left(1500 \mathrm{~g}, 20\right.$ minutes, $\left.4^{\circ} \mathrm{C}\right)$. The protein pellet was washed in $95 \%$ ethanol and resuspended in $10 \mathrm{ml}$ Laemmli buffer. Aliquots of the lysates were taken and stored at $-70^{\circ} \mathrm{C}$.

\section{IMMUNOBLOTTING}

Cell extracts were heated at $100^{\circ} \mathrm{C}$ for five minutes before applying $20 \mu \mathrm{l}$ of cooled sample to a $12 \cdot 5 \%$ polyacrylamide gel with a $5 \%$ stacking gel. Biotinylated molecular weight standards (Bio-Rad) were run alongside samples. Following electrophoresis, the separated proteins were transferred on to nitrocellulose using a semi dry blotter (Ancos) at $180 \mathrm{~mA}$ for one and a half hours at room temperature. Nitrocellulose was blocked in phosphate buffered saline $/ 1 \%$ dried milk powder (blocking buffer) overnight, washed three times in phosphate buffered saline $/ 0.05 \%$ Tween 20 (PBS/T), and cut into strips corresponding to individual lanes. The strips were incubated with test serum samples diluted 1:100 in blocking buffer for one hour at room temperature, then washed in PBS/T (five times for five minutes each) and incubated for one hour with rabbit antihuman immunoglobulins (anti-IgG, IgA, IgM; Dako) conjugated to alkaline phosphatase (1:500 dilution). After washing (twice for five minutes each in PBS/T, twice for five minutes each in veronal acetate buffer), substrate $(1 \cdot 15 \mathrm{mmol} / 1$ 5-bromo-4-chloroindolyl phosphate, $1.22 \mathrm{mmo} / 1$ nitroblue tetrazolium, and $2 \mathrm{mmol} / 1$ magnesium chloride in veronal acetate buffer $\mathrm{pH}$ 9.6) was added and the reaction allowed to continue for 30 minutes. Binding of monoclonal antibodies against Mycobacterium leprae hsp65 was detected using rabbit antimouse antibodies labelled with alkaline phosphatase (Dako).

\section{ENZYME LINKED IMMUNOSORBENT ASSAY}

The recombinant form of the Mycobacterium bovis 65 kilodalton heat shock protein (rhsp65) was coated on to 96 well enzyme linked 
A

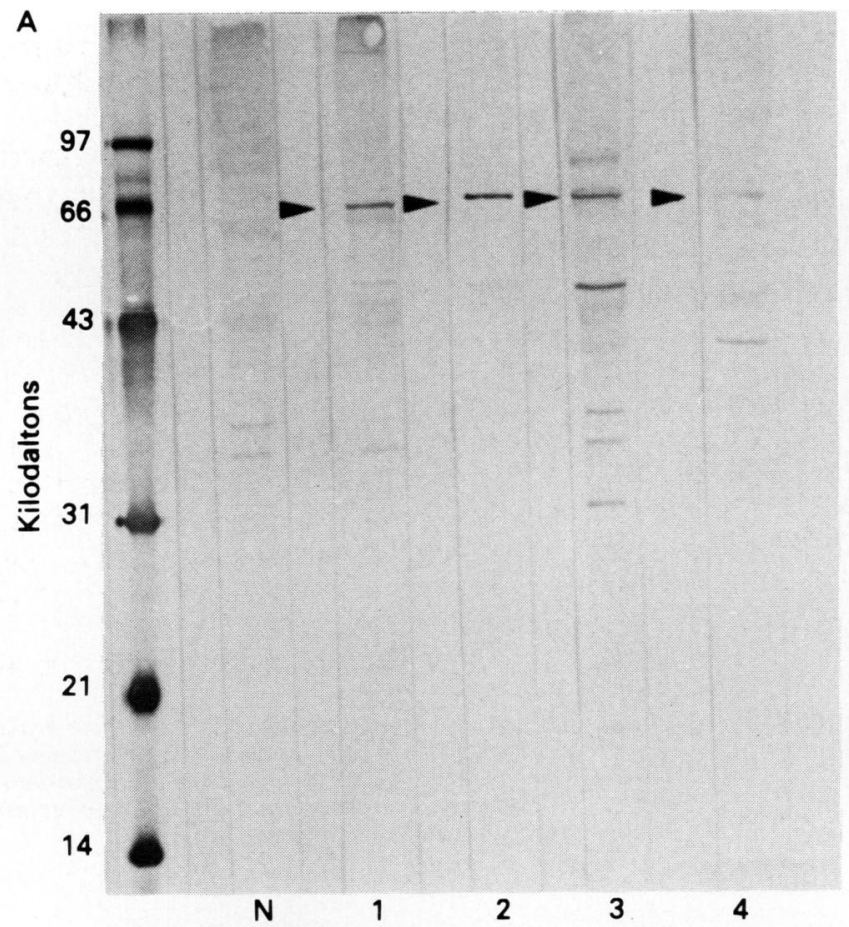

B
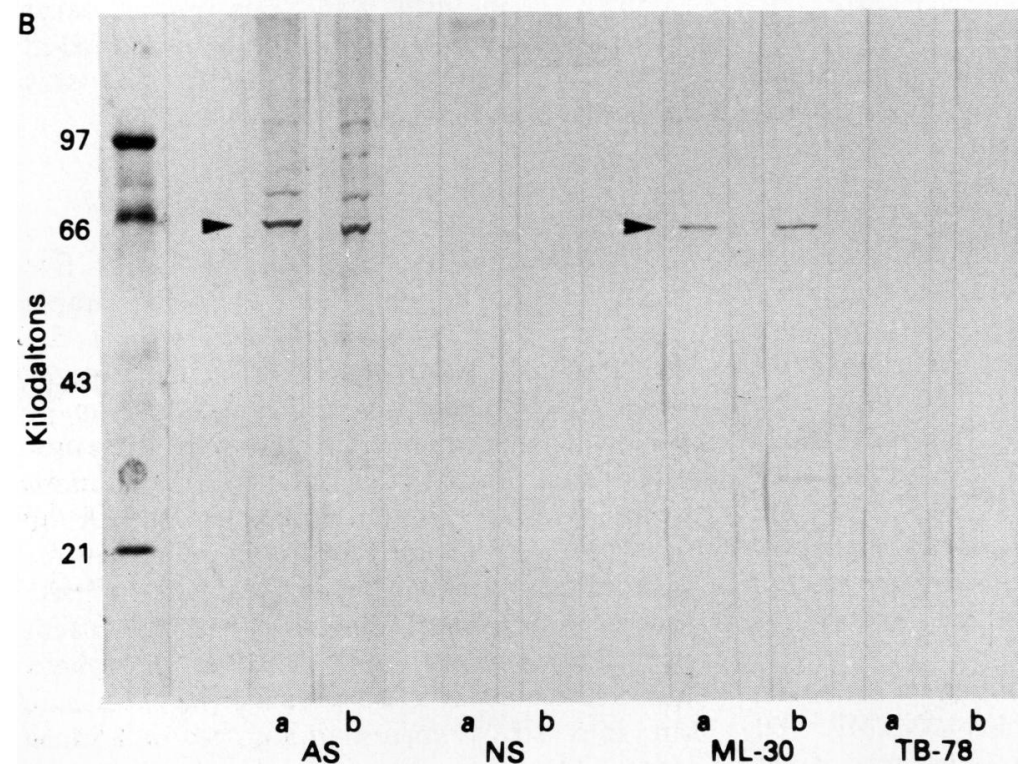

Figure 2 (A) Immunoblots showing the 63 kilodalton protein detected by serum samples from patients with ankylosing spondylitis. This protein was not detected by $96 \%$ of normal serum samples $(N)$. (B) Immunoblots showing the 63 kilodalton protein detected by serum samples from patients with ankylosing spondylitis and the monoclonal antibody $M L-30$ in $(a)$ untreated and $(b)$ heat shocked Schneider cell extracts. The protein was not detected by the monoclonal TB-78 or by the conjugated second antibody $(N S)$.

Features of ankylosing spondylitis in relation to immunoblotting of the insect 63 kilodalton protein and IgA binding to mycobacterial hsp65

\begin{tabular}{|c|c|c|c|c|}
\hline & \multicolumn{2}{|c|}{$\begin{array}{l}\text { Antibody to } 63 \text { kilodalton } \\
\text { insect protein }\end{array}$} & \multicolumn{2}{|c|}{$\begin{array}{l}\text { Antibody to } \\
\text { mycobacterial hsp65 }\end{array}$} \\
\hline & $\begin{array}{l}\text { Positive } \\
(n=21)\end{array}$ & $\begin{array}{l}\text { Negative } \\
(n=25)\end{array}$ & $\begin{array}{l}\text { Positive } \\
(n=19)\end{array}$ & $\begin{array}{l}\text { Negutive } \\
(n=27)\end{array}$ \\
\hline $\begin{array}{l}\text { Age range (years) } \\
\text { Male/female ratio } \\
\text { HLA-B27 positive:negative } \\
\text { Active:inactive disease } \\
\text { Iritis } \\
\text { Inflammatory bowel disease } \\
\text { Psoriasis } \\
\text { Arthritis }\end{array}$ & $\begin{array}{l}23-63 \\
17 / 4 \\
11: 3 \\
6: 15 \\
1 \\
1 \\
2 \\
1\end{array}$ & $\begin{array}{l}26-54 \\
15 / 10 \\
14: 2 \\
11: 14 \\
5 \\
2 \\
2 \\
2\end{array}$ & $\begin{array}{l}24-53 \\
15 / 4 \\
9: 2 \\
8: 11 \\
5 \\
1 \\
1 \\
1\end{array}$ & $\begin{array}{l}23-62 \\
17 / 10 \\
17: 2 \\
10: 17 \\
1 \\
2 \\
3 \\
2\end{array}$ \\
\hline
\end{tabular}

immunosorbent assay (ELISA) plates (Flow Laboratories) at $5 \mu \mathrm{g} / \mathrm{ml}$ in $0.4 \mathrm{~mol} / \mathrm{l}$ sodium chloride, $0.02 \mathrm{~mol} / 1$ TRIS (pH 7.5) (NaCl/Tris) and incubated overnight at $4^{\circ} \mathrm{C}$. Unbound antigen was removed by washing with phosphate buffered saline $(0.145 \mathrm{~mol} / \mathrm{l})$ containing $0.5 \%$ Tween 20 (PBS/T). Non-specific binding sites were blocked with $0.1 \%$ bovine serum albumin (BSA)/PBS/T. After washing, aliquots of test serum samples, diluted 1:50 in BSA/PBS/T in duplicate, were incubated overnight at $4^{\circ} \mathrm{C}$. After further washes with PBS/T, alkaline phosphatase conjugated antihuman antibody (antihuman IgG, IgM, or IgA; Dako) was added ( $1: 1000$ in BSA/PBS/T) and incubated for four hours at room temperature. After further washes the amount of enzyme bound to wells was determined using $p$-nitrophenyl phosphate (Sigma 104) dissolved in $10 \%$ diethanolamine buffer (pH 9.8). The reaction was stopped after 90 minutes by the addition of $3 \mathrm{~mol} / 1$ sodium hydroxide $(50 \mu \mathrm{l})$ and the absorbance values were read immediately at $\mathbf{4 0 5} \mathrm{nm}$ on a Titertek multiscan ELISA reader. Serum samples from 46 patients with AS, 19 patients with RA, 19 patients with SLE, and 20 normal control subjects were tested on three separate occasions. The results quoted are from a single assay in which binding was also measured to wells on separate plates coated only with $\mathrm{BSA} / \mathrm{PBS} / \mathrm{T}$; as no significant binding to BSA was detected the results were not adjusted. Serum samples from normal control subjects were tested on each plate, and these plotted absorbance values represent the mean values obtained from all plates; the coefficient of variation was less than $5 \%$, indicating very low interplate variation, so test serum sample results from different plates in the same assay were not standardised.

\section{STATISTICS}

The ELISA results between groups were compared by the Mann-Whitney $U$ test for data that are not normally distributed, though for defining normal ranges means and notional standard deviations were calculated. Fisher's $\chi^{2}$ test was used to compare frequencies between antibody positive and negative groups (table).

\section{Results}

\section{IMMUNOBLOTTING}

Of 46 serum samples tested from patients with AS, $21(46 \%)$ recognised a protein of molecular weight 63 kilodaltons in the extract of Schneider cells. The 63 kilodalton protein was detected in extracts from unheated and heat shocked cells (fig 2A). The presence of antibody to the 63 kilodalton protein showed no correlation with the age, sex, or HLA-B27 status of the patients, activity or duration of $\mathrm{AS}$, or the presence of peripheral arthritis, psoriasis, inflammatory bowel disease, or acute iritis (table).

Among the groups used for comparison, a protein of the same size was recognised in immunoblots of Schneider cells of serum samples from 1/2 patients with Reiter's syndrome and 4/60 (7\%) patients with SLE. Antibody to the 63 kilodalton protein was not detected in serum samples from patients with 
RA (20 patients), polymyositis (three patients), systemic sclerosis (two patients), and adult Still's disease (two patients). Among $\mathbf{5 0}$ healthy controls, two (4\%) serum samples were positive. None of the three serum samples from healthy HLA-B27 control subjects was positive.

Various other bands were recognised in a random fashion by serum samples from all the disease groups and healthy control subjects. Serum samples containing antibodies to the cellular antigens La, (U1) RNP, PCNA, and Scl-70 recognised proteins in Schneider cell extracts of similar sizes to those reported using mammalian cells, ${ }^{14}$ but the $\mathrm{Ro}, \mathrm{SL}(\mathrm{Ki})$ and Jo-1 antigens were not detected. Serum samples from patients with AS showed no specific reaction with extracts from untreated or heat shocked HeLa cells.
IS THE 63 KILODALTON INSECT PROTEIN RELATED TO THE 65 KILODALTON MYCOBACTERIAL HEAT SHOCK PROTEIN?

Antibodies to heat shock puffs occur in AS, and there are $T$ cell responses to the mycobacterial 65 kilodalton heat shock protein (hsp65) in patients with arthritis. ${ }^{15}$ To look for any cross reactivity between the insect 63 kilodalton and bacterial hsp65 proteins, we examined two murine monoclonal antibodies raised against mycobacterial hsp65 $5^{16}$ for binding to immunoblots of proteins from the Schneider cell extract. Monoclonal TB-78, specific for Mycobacterium leprae, hsp65, did not react with any insect protein, but monoclonal ML-30, known to be less species specific, did bind to a protein band of 63 kilodaltons (fig 2B).

Although there may be more than one insect
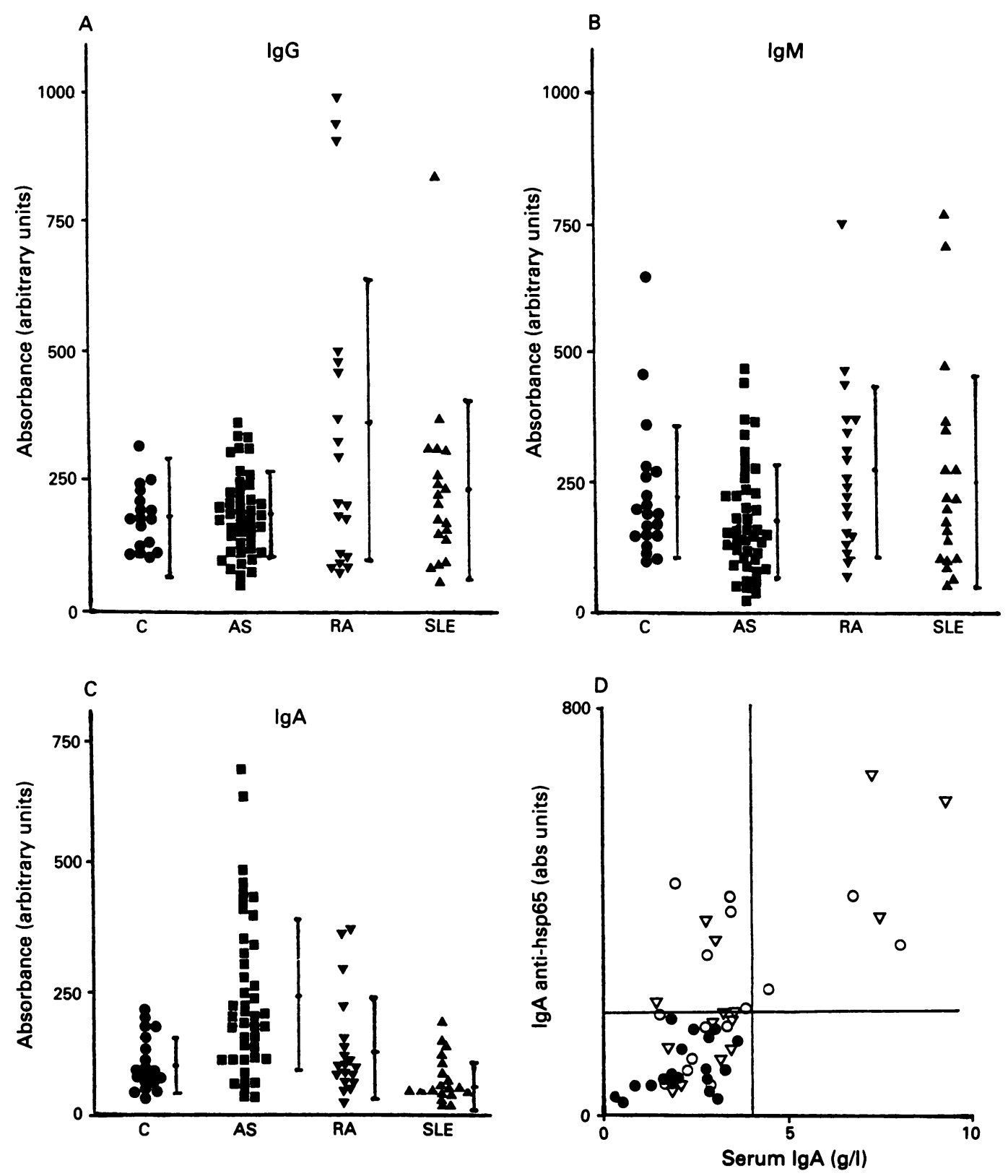

Figure $3(A, B, C)$ Results of the ELISAs for IgG, IgM, and IgA binding to the recombinant 65 kilodalton heat shock protein expressed as scattergrams. (D) Relation between IgA antibodies to hsp65 and total serum IgA in normal serum samples $(O)$ and serum samples from patients with ankylosing spondylitis which are positive $(O)$ or negative $(\nabla)$ for antibodies to the 63 kilodalton drosophila protein. 
protein of this size, the result with ML-30 suggested that the 63 kilodalton antigen identified by serum samples from patients with AS might be cross reactive with the well characterised mycobacterial heat shock protein of similar molecular weight. Therefore, we measured the binding of serum samples from patients with AS to recombinant mycobacterial hsp 65 by ELISA. As shown in fig 3A, B, and C, there was a wide range of binding of serum samples from patients with AS, RA, SLE, and healthy control subjects. The most striking abnormality (shown in fig 3C) was for patients with AS. Nineteen (41\%) of 46 serum samples showed increased IgA binding to the recombinant mycobacterial hsp65 antigen (greater than two standard deviations above that of healthy control subjects), and the mean binding of IgA from patients with AS was higher than for controls $(p<0 \cdot 001$, Mann-Whitney $U$ test).

Serum IgA levels in the AS group (mean $3 \cdot 4$ g/l, SD 2.0) were also significantly higher than the control group (mean $2 \cdot 1 \mathrm{~g} / \mathrm{l}$, SD 0.9 , $\mathrm{p}<0 \cdot 01$, Student's $t$ test), and fig 3B illustrates the correlation between total $\operatorname{IgA}$ and IgA class binding to hsp65 (Pearson's coefficient of rank correlation $r=0.69, \mathrm{p}<0.001)$.

In patients with RA the IgA binding to hsp65 was not significantly different from the control group (Mann-Whitney U test), although binding was increased in four of 19 serum samples (21\%). In a further study of patients with particularly severe rheumatoid disease (vasculitis, fibrosing alveolitis, bronchiectasis, or Felty's syndrome) the frequency of increased IgA binding to hsp 65 was $29 \cdot 4 \%$ of 85 patients (data not shown). IgG binding to hsp65 in patients with RA was increased in six (31\%) of 19 serum samples $(p<0.05$ versus controls, fig 3 ) and $13(15 \%)$ of the further 85 serum samples (data not shown). None of the groups showed increased IgM binding.

In AS antibodies to hsp65 and to the 63 kilodalton insect protein were found in 41 and $46 \%$ of patients respectively, but there was no correlation between the two. Eight patients had antibodies that recognised both proteins, 15 patients had antibodies to neither, and the remainder had antibodies to only one of the proteins (10 to hsp65, 12 to the 63 kilodalton protein).

\section{Discussion}

Immunoblots of Schneider cell extracts show a variety of proteins bound by antibodies in serum samples from normal control subjects and patients with rheumatic diseases. Binding to a particular protein of molecular weight 63 kilodaltons was selectively detected in serum samples from $46 \%$ of the patients with AS, compared with only $4 \%$ of normal control subjects. This finding was relatively specific for AS, though it may extend to reactive arthritis as one of two patients with Reiter's syndrome was positive, and there were occasional positive results in patients with SLE (7\%). Three HLAB27 positive control subjects were negative for antibody to the 63 kilodalton protein. Immunoblotting experiments carried out using protein extracts prepared from the human HeLa cell line failed to show any antigen correlating in terms of size or serum reactivity with the insect derived 63 kilodalton protein.

Our results raise the possibility of cross reactivity with a mycobacterial heat shock protein, hsp65. A monoclonal antibody (ML30) raised against Mycobacterium leprae hsp65 bound to a 63 kilodalton insect protein, and IgA antibodies to recombinant Mycobacterium bovis hsp 65 were found in $41 \%$ of the serum samples from patients with AS by ELISA. The latter may also be explained by increased total IgA in most (but not all) patients (fig 3B), and there was no correlation between $\operatorname{IgA}$ binding to hsp65 and immunoblotting of the 63 kilodalton protein. If the hsp 65 and 63 kilodalton proteins are homologous, the data indicate that at least some of their epitopes do not cross react.

IgA antibodies to hsp65 were not specific for AS, also being found in $19-30 \%$ of patients with RA of varying severity. Binding of $\operatorname{IgM}$ to hsp65 was not significantly different from normal values in any of the patient groups investigated, but in patients with $R A$ the binding of IgG to hsp65 was slightly increased in up to a third of serum samples, in agreement with two previous studies. ${ }^{17} 18$ In SLE, a disease often said to be characterised by polyclonal B cell activation, binding to hsp65 was increased in only $1 / 19$ serum samples for IgG and in none for $\operatorname{IgA}$ or IgM.

Mycobacterial hsp65 is about 50\% homologous with the equivalent human protein, ${ }^{19}$ but we found no binding of serum samples from patients with AS to HeLa cell immunoblots. As to the equivalent insect protein, the degree of homology with mycobacterial hsp65 is unknown, but if the 63 kilodalton protein and hsp65 are homologous, it is possible that antibodies to the 63 kilodalton protein have arisen in response to the hsp65 of an agent relevant to the aetiology of AS, a protein sharing some epitopes with the insect protein and others with bacterial hsp65. Such a hypothetical protein would probably also carry the ML-30 epitope, whose sequence is known. ${ }^{16} 20$

Heat shock had no effect on the expression of the 63 kilodalton protein as judged qualitatively from the immunoblots, but a twofold increase would be difficult to detect in this way. Confirmation of cross reactivity between the 63 kilodalton protein and the mycobacterial heat shock protein hsp65 would implicate the 63 kilodalton antigen as a drosophila heat shock protein. To rheumatologists the heat shock response is a source of some interest and controversy as a potential source of antigenic targets, ${ }^{15}$ as a modulator of $T$ cell function, and as a mechanism by which cells might protect themselves from free radicals at sites of inflammation. ${ }^{21} 22$

Ankylosing spondylitis in the early stages can be difficult to distinguish from mechanical low back pain. In considering the antibody to the 63 kilodalton protein as a test for AS, there is the same drawback as with HLA-B27; even a very low rate of positive results among control subjects $(4 \%$ in this instance) is unacceptable because mechanical low back pain is so much 
more common than AS. Antibody to the 63 kilodalton insect protein was not associated with disease activity, HLA-B27 status, or diseases such as iritis and colitis. However, the antibody to the $\mathbf{6 3}$ kilodalton protein is a further demonstration that there are specific antibody responses in AS, a disease in which an interaction between immunogenetic predisposition and microbial aetiology may shed light on the genesis of autoimmunity in its wider context.

We thank $\mathrm{K}$ Wood for measuring serum immunoglobulins, Dr G Smith for initial work on immunoblotting, Mrs J Hilton for the work with drosophila larvae, Dr J Hartshorne for providing the fruit flies, and also Dr H Pelham and Dr J Sinclair (University of Cambridge) for the Schneider cells. We are grateful to Dr $R$ van der Zee for the mycobacterial recombinant 65 kilodalton heat shock protein, the production and distribution of which were financially supported by the UNDP/World bank/WHO Special Programme for Research and Training in Tropical Diseases. Dr J Programme for Research and Training in Tropical Diseases. Dr antibodies against Mycobacterium leprae, hsp65. This work was supported by the Arthritis and Rheumatism Council and Lupus UK.

1 Calin A. Ankylosing spondylitis. In: Kelley W N, Harris E D, Ruddy S, Sledge C B, eds. Textbook of rheumatology Vol. 2. 3rd ed. Philadelphia: Saunders, 1989: 1031-3.

2 Schwimmbeck P L, Yu D T Y, Oldstone M B A Autoantibodies to HLA B27 in the sera of HLA B27 patients with ankylosing spondylitis and Reiter's syndrome. f Exp Med 1987; 166: 173-81.

3 Trull A K, Ebringer R, Panayi G, Colthorpe D, James DC O, Ebringer A. IgG antibodies to klebsiella pneumoniae in ankylosing spondylitis. Scand 7 Rheumatol 1983; 12: 249-53.

4 Lakomek H-J, Will H, Zech M, Kruskemper H L. A new serological marker in ankylosing spondylitis. Arthritis Rheum 1984; 27: 961-7.

5 Lindquist S, Craig E A. The heat shock proteins. Ann Rev Genet 1988; 22: 631-77.

6 Deshaies R J, Koch B D, Werner-Washburne M, Craig E A, Schekman R. A subfamily of stress proteins facilitates translocation of secretory and mitochondrial precursor polypeptides. Nature 1988; 332: 800-5.
7 Young R A. Stress proteins and immunology. Ann Rev Immunol 1990; 8: 401-20.

8 Ritossa F. A new puffing system induced by temperature shock and DNP in Drosophila. Experimentia 1962;18: $571-3$

9 Moll J H H, Wright V. New York criteria for ankylosing spondylitis: a statistical evaluation. Ann Rheum Dis 1973; 32: 354-63.

10 Ropes M W, Bennett E A, Cobb S, Jacox R, Jesson R. 1958 revision of diagnostic criteria for rheumatoid arthritis. Bull Rheum Dis 1958; 9: 175 .

11 Tan E H, Cohen A S, Fries J F, et al. The 1982 revised criteria for the classification of systemic lupus erythematosus. Arthritis Rheum 1982; 25: 1271-7.

12 Freshey R I, ed. Animal cell culture: a practical approach. Oxford: IRL Press, 1986.

13 Laemmli U K. Cleavage of structural proteins during the assembly of the head of bacteriophage T4. Nature 1970 227: 680 .

14 Bernstein R M, Bunn C C, Hughes G H V, Francoeur A M, Mathews $M$ B. Cellular protein and RNA antigens in autoimmune disease. Mol Biol Med 1984; 2: 105-20.

15 Cohen I R, Holoshitz J, van Eden W, Frankel A. $T$ lymphocyte clones illuminate pathogenesis and affect therapy of experimental arthritis. Arthritis Rheum 1985; 28: $841-5$.

16 Buchanan T M, Normaguchi H, Anderson D C, et al. Characterisation of antibody-reactive epitopes on the 65 kilodalton protein of Mycobacterium leprae. Infect Immun 1987; 55: 1000.

17 Bahr G M, Rook G A W, Al-Saffar M, Van Embden J M Stanford J L, Behbehani K. Antibody levels to mycobacteria in relation to HLA type: evidence of non-HLA-linked high levels of antibody to the $65 \mathrm{kD}$ heat shock protein of levels of antibody to the 65kD heat shock protein of 74: $211-5$.

18 Tsoulfa G, Rook G A W, Van-Embden J M, et al. Raised serum IgG and IgA antibodies to mycobacterial antigens in rheumatoid arthritis. Ann Rheum Dis 1989; 48: 118-23.

19 Jindal S, Dudani A K, Singh B, Harley C B, Gupta R S. Primary structure of human mitochondrial protein homologous to the bacterial and plant chaperonins and to the 65 kilodalton mycobacterial antigens. Mol Cell Biol 1989; 9: 2279-83.

20 Anderson D C, Barry M E, Buchanan T M. Exact definition of species-specific and cross-reactive epitopes of the $65 \mathrm{kD}$ kilodalton protein of Mycobacterium leprae using synthetic peptides. F Immunol 1988; 141: 607-13.

21 Bernstein $\mathrm{R} M$. Heat-shock proteins and arthritis. $\mathrm{Br} \mathcal{J}$ Rheumatol 1989; 28: 369-73.

22 Hurst N F. Stress (heat shock) proteins and rheumatic diseases: new advances or just another band wagon. Rheumatol Int 1990; 9: 271-6. 